Head and neck squamous cell carcinoma (HNSCC) is the sixth most common cause of cancer mortality in the world. Some progress has been made in the therapy of HNSCC, however treatment remains unsatisfactory. Recent studies have shown that different types of long non-coding RNAs (IncRNAs) are dysregulated in HNSCC and correlate with tumor progression, lymph node metastasis, clinical stage and poor prognosis. IncRNAs are a class of functional RNA molecules that can not be translated into proteins but can modulate the activity of transcription factors or regulate changes in chromatin structure. The IncRNAs might have potential of biomarker in HNSCC diagnosis, prognosis, prediction and targeted treatment. In this review we describe the potential role of IncRNAs as new biomarkers and discuss their features including source of origin, extraction methods, stability, detection methods and data normalization and potential function as biomarkers in HNSCC.

Key words: HNSCC, biomarkers, IncRNA, head and neck.

Contemp Oncol (Pozn) 2017; 21 (4): 259-266 DOI: https://doi.org/10.5114/wo.2017.72382

\section{IncRNA in HNSCC: challenges and potential}

\author{
Kacper Guglas ${ }^{1,2 *}$, Marta Bogaczyńska ${ }^{1,3 *}$, Tomasz Kolenda ${ }^{1,2,4 *}$, Marcel Ryśs $\hat{s}^{1,2}$, \\ Anna Teresiak ${ }^{1}$, Renata Bliźniak ${ }^{1}$, Izabela Łasińska ${ }^{5}$, Jacek Mackiewicz ${ }^{5,6,7}$, \\ Katarzyna Lamperska ${ }^{1}$
}

*The authors have contributed equally to this work.

${ }^{1}$ Laboratory of Cancer Genetic, Greater Poland Cancer Centre, Poznan, Poland ${ }^{2}$ Department of Cancer Immunology, Chair of Medical Biotechnology, Poznan University of Medical Sciences, Poznan, Poland

${ }^{3}$ HAN University of Applied Sciences, Nijmegen, Netherlands

${ }^{4}$ Postgraduate School of Molecular Medicine, Medical University of Warsaw, Poland ${ }^{5}$ Department of Medical and Experimental Oncology, Heliodor Swiecicki Clinical Hospital, Poznan University of Medical Sciences, Poland

${ }^{6}$ Department of Biology and Environmental Sciences, Poznan University of Medical Sciences, Poznan, Poland

${ }^{7}$ Department of Diagnostics and Cancer Immunology, Greater Poland Cancer Centre, Poznan, Poland

\section{Head and neck cancers}

Head and neck squamous cell carcinoma (HNSCC) including tumors that occur in the oral cavity is the sixth most common cancer and one of the most common cause of cancer mortality worldwide. Tobacco smoking, alcohol consumption and human papilloma virus (HPV) or Epstein-Barr virus (EBV) infections are the main causes of these malignancies. HNSCC often develops within pre-neoplastic fields of genetically altered cells. HNSCC is divided into many types according to tumor localization: tongue squamous cell carcinoma (TSCC), oral squamous cell carcinoma (OSCC), laryngeal squamous cell carcinoma (LSCC) and nasopharyngeal carcinoma (NPC). For the last decade it has been mainly treated by surgical resection, radical radio(chemo)therapy or systemic treatment alone (e.g. cetuximab, cisplatin, 5-fluorouracyl or taxanes). The 5 -year survival rate has persisted at approximately $43 \%$. The most cases are not early diagnosed until cancer metastases to the regional lymph nodes of the neck what influences on the patients' survival rate [1-4]. Recently pembrolizumab (anty-PD1) has been approved by the U.S. Food and Drug Administration in the second line treatment in patients with advanced HNSCC [5]. However, treatment results remain unsatisfactory despite these efforts. A high proportion of patients who do not respond to standard treatment could get a benefit from personalized therapy based on the molecular diagnostic or targeted therapies. Many studies have shown abnormal changes of many types of RNA (coding and non-coding) in HNSCC patients, which have pivotal role in the cancer biology. This suggests that coding and non-coding RNAs can serve as biomarkers for treatment response prediction or as diagnostic tools $[1,6-8]$. However, the role of long non-coding RNA (In(RNA) are still not deeply understood.

\section{IncRNA - biogenesis, function and role in cancer}

Long non-coding RNAs are a class of functional RNA molecules that are not translated into proteins and consist of at least 200 nucleotides $[9,10]$. However, this remains debatable, and some scientists postulate that IncRNAs have limited protein-coding ability - some transcripts can function in dual roles both as coding and non-coding RNA [11, 12]. It is thought that $93 \%$ of the human genome can be transcribed into RNAs [13]. Approximately $2 \%$ of these transcripts will be translated into proteins, and the remain- 
ing 98\% - called non-coding RNAs (ncRNAs)-will rarely be transcribed [14].

The ncRNAs are classified into two groups. The first group is called constitutive RNA and it includes transfer RNAs (tRNAs), ribosome RNAs (rRNAs), small nuclear RNAs (snRNAs) and small nucleolar RNAs (snoRNAs). The second group, called regulatory RNAs, consists of small interfering RNAs (siRNAs), piRNAs, microRNAs (miRNAs), natural antisense transcripts (NATs), circular RNAs (circRNAs) and long non-coding RNAs (IncRNAs) [15-17]. All ncRNAs, except for tRNAs and rRNAs, are considered "transcriptional noise" [18]. However, IncRNAs are highly transcribed and believed to play roles in more complex biological functions, i.e. regulation of gene expression at the transcriptional level in nucleus (chromatin regulation, alternative splicing of pre-mRNA, DNA demethylation and nuclear organization) or posttranscriptional level in the cytoplasm [18]. It should be noted that large proportions of IncRNAs are closely connected with genes encoded near specific mRNAs and these 'IncRNA-mRNA pairs' influence of each other [19, 20]. Guigo's group reported that IncRNAs exhibit unusual exonic structure and can be alternatively spliced [21]. Another classification of ncRNAs is based on their position relative to protein coding genes: intergenic, intragenic/ intronic and anti-sense [9].

The location in the genome (overlapping with possibly important genes) and difficulties in finding an appropriate model make functional study of IncRNAs challenging. The choice of a suitable model is a problematic issue because of the lack of conservation at the nucleotide sequence level [16], tissue specific expression level [22], transcription initiation from regions rich in repeats [23] and mostly high isoform heterogeneity. The IncRNA isoforms can have different functions [24]. Moreover, recent studies have shown that IncRNAs may have cell-type specificity [25], and their function should be verified in different cell models.

Despite the fact that the vast majority of long non-coding RNAs remain functionally uncharacterized, some of them have been linked with a range biological processes including chromatin modification, regulation of transcription factors, mRNA processing and degradation as well as cell signaling [26]. They also have a vital role in cellular processing, and their deregulated expression has been associated with different types of cancers [27, 28]. Even though many cancer gene-profiling studies have revealed some cancer-associated IncRNAs, there are very few IncRNAs reported for HNSCC.

\section{Features of IncRNA molecules and methods of analysis}

Early diagnosis of cancer results in more effective therapy, and biomarkers to predict and monitor treatment response are urgently needed $[29,30]$. The use of DNA or RNA as a potential biomarker is not innovative, but there are not many DNA or RNA-based markers translated to clinics. Detection of abnormal expression of IncRNAs from tissue, blood or urine samples seems to be easily performed using molecular biology methods nowadays [27, 31, 32].
An ideal biomarker should be simple obtained from the diverse of sources and require simple measurement methodology [33]. However in the case of IncRNAs some problematic questions have arisen and they need to be clarified before implementation of these molecules in the clinical diagnosis.

First of all, it is thought that good biomarker should be easily available. IncRNAs are present in tissue, peripheral blood, serum, saliva, urine or some cell-derived exosomes [31, 32, 34, 35-37], but not all IncRNAs are present in every type of biological material. For example, Tang et al. observed the presence of HOTAIR, HULC, MALAT1, MEG-3, NEAT-1 and UCA1 in malignant and adjacent nonmalignant samples from OSCC patients, but in saliva only HOTAIR and MALAT1 were detectable [36].

High quantity and quality of biomarker molecules are also important. IncRNAs are supposed to be less stable and easier to degrade than miRNAs due to their length. However, Kraus et al. showed in their studies of postmortem brain tissues that some IncRNAs are more stable than miRNAs $[38,39]$. Others also indicated that most IncRNAs are stable (half-life more than 16 h) - especially intragenic and cis-antisense IncRNAs compared with those derived from introns $[10,36]$. The specific IncRNA half-life depends not only on its coding place in the genome and posttranscriptional modifications but also on subcellular localization and function [10]. Moreover, the presence of some IncRNAs in body fluids such as saliva [36], and resistance of plasma IncRNAs to RNase A digestion and overnight incubation at room temperature [37] confirm high stability of these transcripts. On the other hand, analysis of both long coding and non-coding RNA transcripts obtained from archived formalin-fixed paraffin-embedded (FFPE) blocks is difficult because of their low stability [40]. However, this problem can be solved by measuring the expression level of IncRNA by real-time PCR reaction with three different pairs of non-overlapping primers [41].

The next issue refers to the standardization of material sample and the RNA isolation method. There is a lack of specific methods to sample and store material and methodological differences occur. One can compare cancer tissue with adjacent non-cancer samples from the same patient or with samples from healthy donors without a history of cancer. In our opinion, adjacent non-cancer samples are not good reference because of the risk of tumor influence or inflammation. There is also a lack of RNA isolation methods dedicated to IncRNA analysis. IncRNA from tissue and cell lines is usually extracted using standard methods for total RNA isolation based on classical TRIzol or column-based methods [42]. The isolation method seems not affect IncRNA quantification results, but there is no available data supporting this statement. However, column-based approach seems to be better than TRIzol extraction especially in the case of RNA extraction from body fluid [43]. For circulating IncRNA, the sample choice, handling and processing as well as contamination of blood cells influence the sample preparation. Due to coagulation and hemolysis, blood cells release IncRNAs into the serum affecting the results [37, 43, 44]. However, the use of special blood collection tubes can minimize the 
level of background RNA and eliminate false results under quantification [45].

The detection of IncRNA, its quantification and determination of the transcriptional activity of the IncRNA gene (methylation) should be also considered. There are many methods to determine these: i) IncRNA immunoprecipitation; ii) IncRNA in-situ hybridization; iii) Au-NP assay (gold nanoparticle-based); iv) IncRNA northern blot analysis; v) methylation status using HRM (High Resolution Melting); vi) microarray or RNA sequencing; vii) and the most widely used qRT-PCR or new developed ddPCR [31, 32, 46-48]. The choice of proper analysis method depends on kind of study (screening or specific detection), type of material source and costs.

The most common methods in IncRNA studies are hybridization assays especially qRT-PCR. The available qRTPCR IncRNA platforms allows simple and quick quantification of 90 IncRNAs based on CT analysis in one run, while one commercial IncRNA microarray platform can check the expression of more than 30,000 IncRNAs without sophisticated bioinformatics methods required for NGS (Next Generation Sequencing) data extraction [49, 50]. Moreover, microarray experiments seem to be more precise because of the well-validated technology, in contrast to lab-designed qRT-PCR primers, which can differ among laboratories [51]. In addition, the presence of IncRNA isoforms and their polymorphisms influences the function of specific IncRNA [52-54], but there is a lack of information about specific studies. This can make it difficult to compare results.

Microarray or NGS methods are expensive and data analyzing is demanding and probably they will be used only in biomarker research area. The simplicity of performing and low cost as well as availability of IncRNA quantification kits with well-defined workflow seem to make qRTPCR as a gold-standard of IncRNA quantification.

The most popular qRT-PCR method used in IncRNA research is based on SYBR-Green dye and TaqMan probes [42]. qRT-PCR assay requires the right choice of cDNA synthesis method and the proper reference genes. There are no standardized methods for reverse transcription of InCRNA. Some IncRNAs have endogenous polyA tails but others do not possess these elements. Moreover, most IncRNA is present in low copy numbers, and this makes it difficult to quantitate with conventional methods. These IncRNA require the addition of polyA tails and annealing anchor $\mathrm{dT}$ adapters before cDNA synthesis. This approach allows enhance specificity and sensitivity of IncRNA quantification [55]. However, in most studies, the cDNA is prepared using kits containing mixtures of oligo(dT) and random hexamer primers.

Another very important issue is the preparation of RNA to CDNA synthesis, particularly circulating RNA. Qi et al. noted that quantification of circulating RNAs via the NanoDrop spectrophotometer is problematic. They recommended using the same volume of input rather than the same amounts of RNA. However, they showed no evidence supporting this statement [43].

The use of proper reference gene is still problematic in IncRNA expression measurement using qRT-PCR. There is a lack of standardized references, and most IncRNA studies are based on GAPDH, U6 (RNU6B) or ACTB [42]. The mismatched reference influences the results and makes it difficult to compare various studies. The problems with the normalization were observed in the case of miRNA expression studies. The snoRNAs used as normalization for miRNAs are not stably expressed and actually could serve as prognostic factors [51]. This situation suggests that proper normalization is an important step in data presentation and comparison. It should be verified if different types of tissue need specific normalization genes for examination of IncRNA. For example, different IncRNA references are suitable only for brain tissue studies. Some can be applied as universal references in profiling various gliomas and normal tissues [38, 39]. Thus, it should be verified if different cancers need specific IncRNA-related normalizing genes [43]. Fang et al. checked 16 different reference genes regarding cancer, normal and metastasis tissues (such as ACTB, TUBA3, KALPHA1, GAPDH or B2M); for example ACTB was selected as the best normalizer for MALAT1 [55]. One of the open questions is normalization of circulating IncRNA data. Dong et al. verified the utility of ACTB, GAPDH, HPRT, 18S RNA, CYC, and GUSB as the reference genes in the serum of healthy and cancer patients, and ACTB was selected as the best normalizing gene. Moreover, ACTB is stable after temperature changes in serum samples [56].

Despite the numerous problems, IncRNA under proper laboratory conditions seems to be a good candidate as biomarker and this statement is proven by many diagnostic studies [43]. The features of IncRNA molecules as biomarker were summarized in Fig. 1. However, standardization of procedures and definition of specific expression profiles bearing specific clinical information before using IncRNA as biomarkers are urgently needed and are the challenge for the future studies.

\section{IncRNA biomarkers in HNSCC}

Many studies have shown that deregulated expression of IncRNAs can be associated with diabetes [57], leukemia [58], solid cancers [59] or other diseases such as endometriosis [60]. The potential role of IncRNA as biomarkers in cancer such as gastric, colorectal, prostate, lung cancer or HNSCC has already been described [27, 42]. While HOTAIR is deregulated in many cancer types, a few IncRNAs are deregulated in a particular cancer type, i.e. prostate cancer antigen 3 (PCA3) is found only in prostate tissue [61]. The results are promising because PCA3 may be potentially used as a cancer-type specific biomarker.

To date, only nine independent studies show global analysis of IncRNA expression profile in HNSCC: three bioinformatic analysis of available data, four experimental microarray studies and two experimental next generation sequencing studies (Table 1).

Profiling studies revealed that specific IncRNAs expression in cancer tissue is associated with HPV status, known mutations, cancer-related pathways and gene copy number changes [62-66]. We need to remember, that specific global expression analysis is based on the use of some bioinformatics tools $[49,50]$ and the results should be ver- 


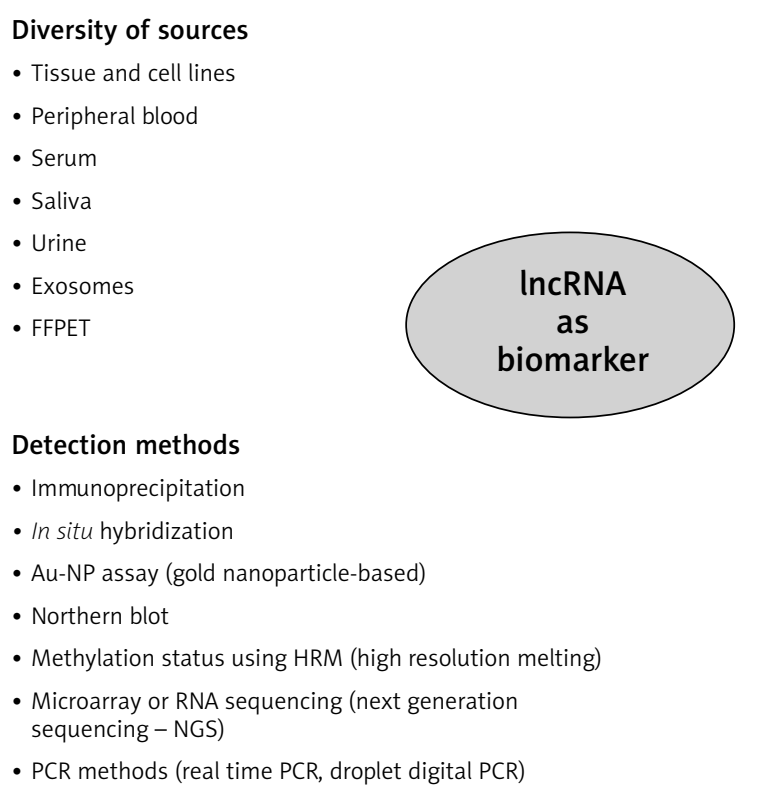

Specificity and sensitivity of detection

- Only some have endogenous polyA tail

- High isoform heterogeneity

- Tissue specific expression

- Present in low copy numbers

- Detectable in body fluids

- Lack of proper reference genes

\section{Stability of molecule}

- Some more stable than miRNAs

- Half-life more than 16 hours

- Resistance to RNase A digestion and incubation at room temperature

- Present in body fluids

Fig. 1. Characteristic of IncRNA molecules as potential biomarker

ified by different methodologies. Thus, most of these studies are not validated using different types of samples or in vitro models. Moreover, the inaccuracies of the results may be caused by differences in examined groups or samples (such as anatomical sites) reflecting genetic diversity. Biological role of only a few IncRNAs dysregulated in HNSCC is well known. The most studied IncRNAs both in vivo and in vitro in HNSCC are HOTAIR, HOTTIP, UCA1, LET, MEG3, MALAT1, H19 and NAG7. They are involved in many important cellular processes such as proliferation, migration and invasion, apoptosis or phenotype regulation. Their exact function in biology of HNSCC has been carefully described by us elsewhere [67].

However, some IncRNAs have a strong prognostic ability for overall survival, disease-free survival, or recurrence-free survival in HNSCC. These IncRNAs described as potential biomarkers are presented in Table 2. Some of IncRNAs are proposed to be independent of gender, organ site, tumor stage or TP53 status [64, 66, 68]. IncRNAs can also be used as virus infection indicators [63], while others may serve as metastasis or disease progression markers [69].

Unfortunately, there is only one study indicating IncRNAs as biomarkers related to response to chemoradiotherapy. Fayda et al. showed that only plasma circulating GAS5 might be a useful predictive biomarker [35]. However, this study is based only on a small group of patients, and these results should be verified in a randomized trial before clinical use [43]. However, expression of IncRNA changes after exposure to chemotherapeutic drugs, and this could maintain drug resistance or sensitivity in cancer cell lines [70-72].

Only one study has indicated a role of IncRNA in radioresistant NPC cell lines. Li et al. used NGS technology and showed some previously known and some novel IncRNAs are dysregulated in radioresistant cell (Rs) line compared to the parental line. Three pairs of IncRNA-mRNA in CNE-2-
Rs and 6-10B-Rs cell lines have been described. The discovered IncRNAs: n373932, n409627 and n386034, regulate SLITRK5, PRSS12 and RIMKLB mRNAs, respectively. Only CNE-2-Rs cells show a slight change in IncRNAs-mRNAs. In the case of 6-10B-RSs, there is strong down-regulation of n373932 IncRNA and up-regulation of STITRK5 mRNA. Moreover, the expression of n373932 and SLITRK5 is negatively correlated in NPC patients [73]. More in vivo and in vitro studies are needed to define exact role of specific IncRNA in chemo- and radioresponse and next validation of predictive IncRNA panel in clinical practice.

\section{Conclusions and future perspectives}

IncRNAs, including the ones described here, are aberrantly expressed in a number of different cancers and were characterized as molecules with a great impact. These recently discovered RNA molecules affect the hallmarks of carcinogenesis including proliferation, metastasis and apoptosis. Moreover, existing reports indicate the potential role of IncRNA as a new class of biomarkers. However, there are some challenges and problems to take and solve before use. First of all, there is only a few data regarding specific IncRNA in HNSCC. Despite the fact that several studies have shown global changes in IncRNA expression profile in HNSCC, the validated panel was not proposed. Moreover, most studies are based on a small study group, and it is difficult to compare them to TCGA-based analyzes. Some of IncRNAs described in this review play pivotal roles in HNSCC and might be biomarkers of treatment response. However, only a few studies have focused on IncRNA after irradiation or chemoexposure. The exact role of specific IncRNAs in regulation and response to radiation and chemotherapy used in HNSCC is unknown and requires future studies. The next issue is lack of well-validated methodology to use IncRNA in diagnostics such as different detection methods as well as use of non-specific or unsuitable normalization genes, which influence on the results. 
Table 1. Characteristic of global IncRNA profiling studies in HNSCC

\begin{tabular}{|c|c|c|}
\hline Study & Analysis & Results description \\
\hline $\begin{array}{l}\text { Zou } \\
\text { et al. } \\
{[62,63]}\end{array}$ & $\begin{array}{l}\text { Bioinformatic analysis of } \\
\text { RNA-seq data sets (TCGA data } \\
\text { from UCSC Cancer Genomics } \\
\text { Hub) of } 40 \text {-tumour-adjacent } \\
\text { normal pairs and } 363 \text { additional } \\
\text { unpaired tumors }\end{array}$ & $\begin{array}{l}\text { - } 9681 \text { IncRNA transcripts significantly changed; } 596 \text { lincRNAs of them strong } \\
\text { dysregulated in HNSCC (up or downregulated) } \\
\text { - Confirmation of GAS5 and MEG3 down-regulation and identification of H19 and PCAT-1 } \\
\text { dysregulation (all tumor sites) } \\
\text { - Different tumor sites analysis of } 39 \text { matched samples revealed: } \\
\text { i) OSCC - } 777 \text { IncRNAs changed } \\
\text { ii) TSCC - } 1020 \text { IncRNAs changed } \\
\text { iii) LSCC - } 657 \text { IncRNAs changed } \\
\text { - } 276 \text { lincRNAs significantly predict patients' OS (over and underexpression depends } \\
\text { on lincRNA); } \\
\text { - } 256 \text { asSOciated with TP53 mutation and } 269 \text { with TP53-3p co-occurrence }\end{array}$ \\
\hline $\begin{array}{l}\text { Nohata } \\
\text { et al. } \\
{[64]}\end{array}$ & $\begin{array}{l}\text { Bioinformatic analysis of RNA- } \\
\text { seq data sets (TCGA data from } \\
\text { The Atlas of Noncoding RNAs in } \\
\text { Cancer - TANRIC) of } 468 \text { tumor } \\
\text { samples } \\
\text { Analysis of sequencing data of } \\
\text { OPC-22 panel (cell lines) }\end{array}$ & $\begin{array}{l}\text { - } 728 \text { IncRNA transcripts changed between normal and tumor samples ( } 212 \text { up- and } 516 \\
\text { down-regulated) } \\
\text { - Significant connection of } 55 \text { IncRNAs with patient's prognosis in OS or DFS (reduced or } \\
\text { increased OS or DFS - depending on type of InCRNA) } \\
\text { - } 27 \text { upregulated IncRNAs in HPV+ cell lines and } 140 \text { up-regulated in HPV+ tumors from } \\
\text { TCGA } \\
\text { - } 30 \text { IncRNAs downregulated in TP53 mutated tumors }\end{array}$ \\
\hline $\begin{array}{l}\text { Yang } \\
\text { and } \\
\text { Deng } \\
{[65]}\end{array}$ & $\begin{array}{l}\text { Microarray analysis (mRNA and } \\
\text { IncRNA) of } 6 \text { pairs of NPC and } \\
\text { chronic nasopharyngitis (CNP) } \\
\text { samples and qRT-PCR validation }\end{array}$ & $\begin{array}{l}\text { - } 856 \text { IncRNA transcripts changed between NPC and CNP ( } 425 \text { up- and } 431 \text { down- } \\
\text { regulated) } \\
\text { - Changed IncRNA connected with apoptosis, cell growth and proliferation revealed by } \\
\text { IncRNA-mRNA interaction analysis, migration and movement or cell differentiation and } \\
\text { interaction with JAK-STAT signaling pathway }\end{array}$ \\
\hline $\begin{array}{l}\text { Zhang } \\
\text { et al. } \\
{[69]}\end{array}$ & $\begin{array}{l}\text { Microarray analysis of randomly } \\
\text { paired } 3 \text { metastatic and } \\
4 \text { primary NPC tumor samples } \\
\text { and qRT-PCR validation }\end{array}$ & $\begin{array}{l}\text { - } 8088 \text { IncRNA transcripts changed between metastatic and primary samples (3778 up- } \\
\text { and } 4310 \text { down-regulated) } \\
\text { - Expression level of ENST00000438550 as an independent indicator of disease } \\
\text { progression in NPC patients }\end{array}$ \\
\hline $\begin{array}{l}\text { Zhou } \\
\text { et al. } \\
{[74]}\end{array}$ & $\begin{array}{l}\text { Microarray analysis of } \\
3 \text { paired tumor and adjacent } \\
\text { noncancerouse samples from } \\
\text { hypopharyngeal squamose cell } \\
\text { carcinoma (HSCC) patients and } \\
\text { qRT-PCR validation }\end{array}$ & $\begin{array}{l}\text { - AB209630 and AB019562 indicated as changed in HNSCC (AB209630 low expressed, } \\
\text { AB019562 high expressed), which influence on cell growth, colony formation, invasion } \\
\text { and apoptosis/cell death in FaDu } \\
\text { - High expression of AB209630 correlated with better OS }\end{array}$ \\
\hline $\begin{array}{l}\text { Ren } \\
\text { et al. } \\
{[70]}\end{array}$ & $\begin{array}{l}\text { Next generation sequencing and } \\
\text { qRT-PCR validation }\end{array}$ & $\begin{array}{l}\text { - } 2670 \text { known and } 4820 \text { novel IncRNAs changed in paclitaxel-resistant CNE-2 compared to } \\
\text { parental CNE-2 cell line } \\
\text { - n375709 - the most overexpressed IncRNA; influence on sensitivity to paciltaxel in vivo }\end{array}$ \\
\hline $\begin{array}{l}\text { Zhang } \\
\text { et al. } \\
{[66]}\end{array}$ & $\begin{array}{l}\text { Bioinformatic analysis of } \\
\text { microarray data sets (GSE25099 } \\
\text { from Gene Expression Omnibus } \\
\text { database) of } 57 \text { OSCC samples } \\
\text { and } 22 \text { normal sample }\end{array}$ & $\begin{array}{l}\text { - } 160 \text { IncRNA transcripts changed between OSCC and normal samples (41 up- and } 119 \\
\text { down-regulated) } \\
\text { - Up-regulated targets of IncRNA connected with immune response, response to } \\
\text { wounding, inflammatory response and regulation of proliferation; down-regulated } \\
\text { targets of IncRNA connected with epidermis development }\end{array}$ \\
\hline $\begin{array}{l}\text { Li et al. } \\
{[73]}\end{array}$ & $\begin{array}{l}\text { Next generation sequencing and } \\
\text { qRT-PCR of radio-resistant CNE- } \\
\text { 2-Rs and parental CNE-2 cell } \\
\text { lines (nasopharengynal) and } \\
\text { qRT-PCR validation }\end{array}$ & $\begin{array}{l}\text { - } 310 \text { up-regulated and } 471 \text { down-regulated of known IncRNAs in radioresistant CNE-2-Rs } \\
\text { compared to parental CNE-2 cell line } \\
\text { - } 3 \text { novel IncRNA Unigene } 8485 \text {, Unigene } 8588 \text { and down-regulated Unigene3434 } \\
\text { - } 13 \text { pairs of IncRNA-mRNA associated with radioresistance in CNE-2-Rs cell line }\end{array}$ \\
\hline $\begin{array}{l}\text { Zhang } \\
\text { et al. } \\
{[75]}\end{array}$ & $\begin{array}{l}\text { Microarray analysis (IncRNA and } \\
\text { mRNA) of } 7 \text { NPC tumor samples } \\
\text { and adjacent non-tumor } \\
\text { samples and qRT-PCR validation }\end{array}$ & $\begin{array}{l}\text { - } 481 \text { IncRNA transcripts changed between NPC and normal samples ( } 231 \text { up- and } 250 \\
\text { down-regulated) as well as } 766 \text { mRNA transcripts ( } 323 \text { up- and } 443 \text { down-regulated) } \\
\text { - Up-regulated IncRNAs mainly localized on chromosomes: } 12,2,1 \text { ( } 8.7 \% \text { of IncRNA } \\
\text { transcripts) } \\
\text { - LncRNA-mRNA pairs implicated in processes such as: regulation of transcription, } \\
\text { macromolecule metabolic and biosynthesis, nerve development, immunological synapse } \\
\text { or signaling pathways: B and T cell receptor transmembrane and TGF- } \beta \text { receptor }\end{array}$ \\
\hline
\end{tabular}

We supposed, that future cancer diagnostic panels will likely consist of a wide variety of genes-both protein coding and non-coding. Such a platform will offer a detailed description of the nature of the tumor, and this will allow personalized treatment of HNSCC.
The examples presented here are just the tip of the iceberg. Knowledge about IncRNA is evolving. A lot of work was done to explain the role of this molecules in the cancer biology, but much more should be do to use this knowledge in clinical practice. 
Table 2. IncRNAs described as potential biomarkers in HNSCC

\begin{tabular}{|c|c|c|}
\hline IncRNA & Description & Ref. \\
\hline NEAT-1 & $\begin{array}{l}\text { - Significant up-regulated only in metastatic OSCC samples; not found in patients' saliva } \\
\text { - Over-expressed in LSCC }\end{array}$ & $\begin{array}{l}{[62,36} \\
75,76]\end{array}$ \\
\hline HOTAIR & $\begin{array}{l}\text { - Over-expressed in LSCC samples; correlated with poor differentiation cancers, lymph node metastasis, } \\
\text { resistance to apoptosis and more advanced clinical stage } \\
\text { - Over-expressed in OSCC of metastatic and non-metastatic tumors; correlated with lymph node metastasis, } \\
\text { tumor size, clinical stage and histological differentiation; associated with poor OS and DFS } \\
\text { - Increased expression of exosomal HOTAIR and miR-21 in LSCC patients' blood, correlated with clinical } \\
\text { stages, T classification and lymph node metastasis; miR-21 and HOTAIR can discriminate the patients who } \\
\text { are at the risk of developing LSCC } \\
\text { - Independent prognostic marker for patients' progression and survival in the NPC patients }\end{array}$ & $\begin{array}{l}{[36,} \\
77-81]\end{array}$ \\
\hline HOTTIP & $\begin{array}{l}\text { - Over-expressed in TSCC samples; associated with clinical stage, tumor size, distant metastasis and } \\
\text { patients' OS; an independent poor prognostic factor }\end{array}$ & [32] \\
\hline UCA1 & $\begin{array}{l}\text { - Over-expressed in TSCC samples; correlated with lymph node metastasis - potentially prognostic indicator } \\
\text { of lymph node metastasis } \\
\text { - In OSCC samples lack of differences in expression levels between samples and match adjacent non-tumor } \\
\text { samples }\end{array}$ & {$[36,82]$} \\
\hline $\begin{array}{l}\text { AC026166.2- } \\
\text { 001 \& RP11- } \\
\text { 169D4.1-001 }\end{array}$ & $\begin{array}{l}\text { - Down-regulated in LSCC samples and metastatic cervical lymph nodes; low expression associated with } \\
\text { poor prognosis }\end{array}$ & [83] \\
\hline GAS5 & $\begin{array}{l}\text { - Down-regulated in HNSCC and correlated with poor prognosis } \\
\text { - Circulating GAS5 as a prediction factor of patients' response to radical chemoradiotherapy }\end{array}$ & $\begin{array}{l}{[62,35,} \\
51]\end{array}$ \\
\hline Inc-JPHI-7 & - Significant associated with survival of both HPV+ and HPV- patients and advanced tumor stage & [63] \\
\hline LET & $\begin{array}{l}\text { - Down-regulated in NPC samples; correlated with clinical stage, tumor size and lymph node involvement; } \\
\text { low expression correlated with poor RFS and OS }\end{array}$ & [68] \\
\hline InCRNA-ROR & - Over-expressed in NPC samples and influence on chemoresistance & [72] \\
\hline XIST & $\begin{array}{l}\text { - Over-expressed in NPC samples and NPC cancer cell lines; connected with poorer OS; an independent risk } \\
\text { factor for prognosis }\end{array}$ & [84] \\
\hline MEG3 & $\begin{array}{l}\text { - Down-regulated in TSCC samples and cell lines; correlated with tumor size; low level associated with } \\
\text { poorer OS } \\
\text { - Lack of differences in expression levels between OSCC samples and matched adjacent non-tumor samples }\end{array}$ & {$[36,85]$} \\
\hline MALAT1 & $\begin{array}{l}\text { - Over-expressed in LSCC, OSCC and TSCC samples - especially in the case of metastatic TSCC correlated } \\
\text { with cervical lymph node metastasis } \\
\text { - In OSCC low expression significantly increased patients' OS } \\
\text { - Lack of differences in expression levels between OSCC samples and match adjacent non-tumor samples } \\
\text { and no differences between metastatic and non-metastatic samples }\end{array}$ & $\begin{array}{l}{[36,55} \\
71,86]\end{array}$ \\
\hline H19 & $\begin{array}{l}\text { - Over-expressed in LSCC samples; correlated with the tumor grade, differentiation, neck nodal metastasis, } \\
\text { clinical stage and poorer OS }\end{array}$ & [87] \\
\hline $\begin{array}{l}\text { lincRNA } \\
\text { NAG7 } \\
\text { (LINC00312) }\end{array}$ & $\begin{array}{l}\text { - Down-regulated in NPC samples; correlated with lymph node metastasis, clinical stage and tumor size; } \\
\text { high expression of LINCO0312 is associated with better DFS and OS in patients without lymph node } \\
\text { metastasis, in patients with positive lymph nodes the higher expression of LINC00312 significantly } \\
\text { connected with poor DFS and OS }\end{array}$ & [12] \\
\hline NKILA & - Down-regulated in TSCC samples; correlated with clinical parameters, metastasis and poor DFS and OS & [88] \\
\hline
\end{tabular}

This work was supported by Greater Poland Cancer Centre-grant No.: 21/2015 (113) and grant No.: 13/2016 (128). English language revision and editing was made by American Manuscript Editors - americanmanuscripteditors.com.

The authors declare no conflict of interest.

\section{References}

1. Zhi IX, Lamperska K, Golusinski P, Schork NJ, Luczewski L, Kolenda T et al. Gene expression analysis of head and neck squamous cell carcinoma survival and recurrence. Oncotarget 2015; 6: 547-55.
2. Tsang CM, Tsao SW. The role of Epstein-Barr virus infection in the pathogenesis of nasopharyngeal carcinoma. Virol Sin 2015; 30: 107-21.

3. Marur S, Forastiere AA. Head and Neck Squamous Cell Carcinoma: Update on Epidemiology, Diagnosis, and Treatment. Mayo Clin Proc 2016; 91: 386-96.

4. van Oijen MG, Slootweg PJ. Oral field cancerization: carcinogen induced independent events or micrometastatic deposits? Cancer Epidemiol Biomarkes Prev 2000; 9: 249-56.

5. Fuereder T. Immunotherapy for head and neck squamous cell carcinoma. Memo. 2016; 9: 66-9.

6. Victoria Martinez B, Dhahbi JM, et al. Circulating small non coding RNA signature in head and neck squamous cell carcinoma. Oncotarget 2015; 6: 19246-63. 
7. Lamperska K, Kozlowski P, Kolenda T, et al. Unpredictable changes of selected miRNA in expression profile of HNSCC. Cancer Biomark 2016; 16: 55-64.

8. Kolenda T, Przybyła W, Teresiak A, Mackiewicz A, Lamperska K. The mystery of let-7d - a small RNA with great power. Contemp Oncol (Pozn) 2014; 18: 293-301.

9. Mercer TR, Dinger ME, Mattick JS. Long non-coding RNAs: insights into functions. Nat Rev Genet 2009; 10: 155-9.

10. Clark MB, Johnston RL, Inostroza-Ponta M, Fox AH, Fortini E, Moscato P, Dinger ME, Mattick JS. Genome - wide analysis of long noncoding RNA stability. Genome Res 2012; 22: 885-98.

11. Dinger ME, Pang KC, Mercer TR, Mattick JS. Differentiating protein coding and noncoding RNA: challenges and ambiguities. PLoS Comput Biol 2008; 4: e1000176.

12. Zhang W, Huang C, Gong Z, et al. Expression of LINC00312, a long intergenic non-coding RNA, is negatively correlated with tumor size but positively correlated with lymph node metastasis in nasopharyngeal carcinoma. J Mol Histol 2013; 44: 545-54.

13. Birney E, Stamatoyannopoulos JA, Dutta A, Guigó R, Gingeras TR, et al.; ENCODE Project Consortium. Identification and analysis of functional elements in 1\% of the human genome by the ENCODE pilot project. Nature 2007; 447: 799-816.

14. Carninci P, Kasukawa T, Katayama S, et al. The transcriptional land scape of the mammalian genome. Science 2005; 309: 1559-63.

15. Zhang Y, Yang L, Chen LL. Life without a tail: new formats of long noncoding RNAs. Int J Biochem Cell Biol 2014; 54: 338-49.

16. Furuno M, Pang KC Ninomiya N, et al. Clusters of internally primed transcripts reveal novel long noncoding RNAs. PLoS Genet 2006; 2: e37.

17. Memczak S, Jens M, Elefsinioti A, et al. Circular RNAs are a large class of animal RNAs with regulatory potency. Nature 2013; 495: 333-8.

18. Kun Y, Arfat Y, Li D, Zhao F, et al. Structure Prediction: New Insights into Decrypting Long Noncoding RNAs. Int J Mol Sci 2016; 17: 132.

19. Kong XP, Yao J, Luo W, Feng FK, Ma JT, Ren YP, Wang DL, Bu RF. The expression and functional role of a FOXC1 related mRNA-IncRNA pair in oral squamous cell carcinoma. Mol Cell Biochem 2014; 394: 177-86.

20. Sigova AA, Mullen AC, Molinie B, et al. Divergent transcription of long noncoding RNA/mRNA gene pairs in embryonic stem cells. Proc Natl Acad Sci U S A 2013; 110: 2876-81.

21. Derrien T, Johnson R, Bussotti G, et al. The GENCODE v7 catalog of human long noncoding RNAs: Analysis of their gene structure, evolution, and expression. Genome Res 2012; 22: 1775-89.

22. Cabili MN, Trapnell C, Goff L, Koziol M, Koziol M, Tazon-Vega B, Regev A, Rinn JL. Integrative annotation of human large intergenic noncoding RNAs reveals global properties and specific subclasses. Genes Dev 2011; 25: 1915-27.

23. Kelley D, Rinn J. Transposable elements reveal a stem cell-specific class of long noncoding RNAs. Genome Biol 2012; 13: R107.

24. Hoffmann MJ, Dehn J, Droop J, et al. Truncated Isoforms of IncRNA ANRIL Are Overexpressed in Bladder Cancer, But Do Not Contribute to Repression of INK4 Tumor Suppressors. Non-Coding RNA 2015; 1: 266-84.

25. Huarte M, Guttman M, Feldser D, et al. A large intergenic noncoding RNA induced by $p 53$ mediates global gene repression in the p53 response. Cell 2010; 142: 409-19.

26. Chang HY, Schmitt AM. Long Noncoding RNAs in Cancer Pathways. Cancer Cell 2016; 29: 452-63.

27. Yarmishyn AA, Kurochkin IV. Long noncoding RNAs: a potential novel class of cancer biomarkers. Front Genet 2015; 6: 145.

28. Jiang C, Li X, Zhao H, Liu H. Long non-coding RNAs: potential new biomarkers for predicting tumor invasion and metastasis. Mo Cancer 2016; 15: 62.

29. Ahlawat P, Rawat S, Kakria A, Pal M, Chauhan D, Tandon S, Jain S. Tumour volumes: Predictors of early treatment response in locally advanced head and neck cancers treated with definitive chemoradiation. Rep Pract Oncol Radiother 2016; 21: 419-26.

30. González Ferreira JA, Jaén Olasolo J, Azinovic I, Jeremic B. Effect of radiotherapy delay in overall treatment time on local control and survival in head and neck cancer: Review of the literature. Rep Pract Oncol Radiother 2015; 20: 328-39.
31. Eissa S, Matboli M, Essawy NO, Shehta M, Kotb YM. Rapid detection of urinary long non-coding RNA urothelial carcinoma associated one using a PCR-free nanoparticle-based assay. Biomarkers 2015; 20: 212-7.

32. Zhang H, Zhao L, Wang YX, Xi M, Liu SL, Luo LL. Long non-coding RNA HOTTIP is correlated with progression and prognosis in tongue squamous cell carcinoma. Tumour Biol 2015; 36: 8805-9.

33. Kolenda T, Teresiak A, Kapałczyńska M, Przybyła W, Zajączkowska M, Bliźniak R, Masternak MM, Golusinski P, Golusinski W. Let-7d and miR-18a as biomarkers of head and neck cancers. Lett Oncol Sci 2015; 12: 37-47.

34. Gezer U, Özgür E, Cetinkaya M, Isin M, Dalay N. Long non-coding RNAs with low expression levels in cells are enriched in secreted exosomes. Cell Biol Int 2014; 38: 1076-9.

35. Fayda M, Isin M, Tambas M, et al. Do circulating long non-coding RNAs (IncRNAs) (LincRNA-p21, GAS 5, HOTAIR) predict the treatment response in patients with head and neck cancer treated with chemoradiotherapy? Tumour Biol 2016; 37: 3969-78.

36. Tang H, Wu Z, Zhang J, Su B. Salivary IncRNA as a potential marker for oral squamous cell carcinoma diagnosis. Mol Med Rep 2013; 7: 761-6.

37. Zhou X, Yin C, Dang Y, Ye F, Zhang G. Identification of the long non-coding RNA H19 in plasma as a novel biomarker for diagnosis of gastric cancer. Sci Rep 2015; 5: 11516.

38. Kraus TF, Greiner A, Guibourt V, Lisec K, Kretzschmar HA. Identification of Stably Expressed IncRNAs as Valid Endogenous Controls for Profiling of Human Glioma. J Cancer 2015; 6: 111-9.

39. Kraus TF, Greiner A, Guibourt V, Kretzschmar HA. Long non-coding RNA normalisers in human brain tissue. J Neural Transm (Vienna) 2015; 122: 1045-54.

40. Kokkat TJ, Patel MS, McGarvey D, LiVolsi VA, Baloch ZW. Archived formalin-fixed paraffin-embedded (FFPE) blocks: A valuable underexploited resource for extraction of DNA, RNA, and protein. Biopreserv Biobank 2013; 11: 101-6.

41. Kong H, Zhu M, Cui F, Wang S, Gao X, Lu S, Wu Y, Zhu H. Quantitative assessment of short amplicons in FFPE-derived long-chain RNA. Sci Rep 2014; 4: 7246.

42. Shi T, Gao G, Cao Y. Long Noncoding RNAs as Novel Biomarkers Have a Promising Future in Cancer Diagnostics. Dis Markers 2016; 2016: 9085195.

43. Qi P, Zhou XY, Du X. Circulating long non-coding RNAs in cancer: current status and future perspectives. Mol Cancer 2016; 15: 39.

44. Pritchard CC, Kroh E, Wood B, Arroyo JD, Dougherty KJ, Miyaji MM, Tait JF. Tewari M. Blood cell origin of circulating microRNAs: a cautionary note for cancer biomarker studies. Cancer Prev Res (Phila) 2012; 5: 492-7.

45. Qin J, Williams TL, Fernando MR. A novel blood collection device stabilizes cell-free RNA in blood during sample shipping and storage. BMC Res Notes 2013; 6: 380.

46. Feng Y, Hu X, Zhang Y, Zhang D, Li C, Zhang L. Methods for the Study of Long Noncoding RNA in Cancer Cell Signaling Methods. Methods Mol Biol 2014; 1165: 115-43.

47. Wojdacz TK, Dobrovic A, Algar EM. Rapid detection of methylation change at $\mathrm{H} 19$ in human imprinting disorders using methylation-sensitive high-resolution melting. Hum Mutat 2008; 29: 1255-60.

48. Dodd DW, Gagnon KT, Corey DR. Digital quantitation of potential therapeutic target RNAs. Nucleic Acid Ther 2013; 23: 188-94.

49. Oleksiewicz U, Tomczak K, Woropaj J, Markowska M, Stępniak P, Shah PK. Computational characterisation of cancer molecular profiles derived using next generation sequencing. Contemp Oncol (Pozn) 2015; 19 (1A): A78-A91.

50. Tomczak K, Czerwińska P, Wiznerowicz M. The Cancer Genome Atlas (TCGA): an immeasurable source of knowledge. Contemp Oncol (Pozn) 2015; 19 (1A): A68-77.

51. Gee HE, Buffa FM, Camps C, The small-nucleolar RNAs commonly used for microRNA normalisation correlate with tumour pathology and prognosis. Br J Cancer 2011; 104: 1168-77.

52. Desai S, Ding M, Wang B, Lu Z, Zhao Q, Shaw K, et al. Tissue-specific isoform switch and DNA hypomethylation of the pyruvate kinase PKM gene in human cancers. Oncotarget 2014; 5: 8202-10. 
53. Pang KC, Frith MC, Mattick JS. Rapid evolution of noncoding RNAs: lack of conservation does not mean lack of function. Trends Genet 2006; 22: 1-5.

54. Hüttenhofer A, Schattner P, Polacek N. Non-coding RNAs: hope or hype? Trends Genet 2005; 21: 289-97.

55. Fang Z, Zhang S, Wang Y, et al. Long non-coding RNA MALAT-1 modulates metastatic potential of tongue squamous cell carcinomas partially through the regulation of small proline rich proteins. BMC Cancer 2016; 16: 706

56. Dong L, Qi P, Xu MD, et al. Circulating CUDR, LSINCT-5 and PTENP1 long noncoding RNAs in sera distinguish patients with gastric cancer from healthy controls. Int J Cancer 2015; 137: 1128-35.

57. Reddy MA, Chen Z, Park JT, et al. Regulation of inflammatory phenotype in macrophages by a diabetes-induced long noncoding RNA. Diabetes 2014; 63: 4249-61.

58. Trimarchi T, Bilal E, Ntziachristos P, Fabbri G, Dalla-Favera R, Tsirigos A Aifantis I. Genome-wide mapping and characterization of Notch-regulated long noncoding RNAs in acute leukemia. Cell 2014; 158: 593-606.

59. Huarte M. The emerging role of IncRNAs in cancer. Nature Med 2015; 21: 1253-61.

60. Wang WT, Sun YM, Huang W, He B, Zhao YN, Chen YQ. Genome-wide long non-coding RNA analysis identified circulating LncRNAs as nove non-invasive diagnostic biomarkers for gynecological disease. Sci Rep 2016; 6: 23343.

61. Bussemakers MJ, van Bokhoven A, Verhaegh GW, et al. DD3: a new prostate-specific gene, highly overexpressed in prostate cancer. Cancer Res 1999; 59: 5975-9.

62. Zou AE, Ku J, Honda TK, et al. Transcriptome sequencing uncovers nove long noncoding and small nucleolar RNAs dysregulated in head and neck squamous cell carcinoma. RNA 2015; 21: 1122-34.

63. Zou AE, Zheng H, Saad MA, Rahimy M, Ku J, Kuo SZ, et al. The non-coding landscape of head and neck squamous cell carcinoma. Oncotarget 2016; 7: 51211-22.

64. Nohata N, Abba MC, Gutkind JS. Unraveling the oral cancer IncRNAome: Identification of novel IncRNAs associated with malignant progression and HPV infection. Oral Oncol 2016; 59: 58-66.

65. Yang OO, Deng YF. Genome-wide analysis of long non-coding RNA in primary nasopharyngeal carcinoma by microarray. Histopathology 2015; 66: 1022-30.

66. Zhang S, Tian L, Ma P, Sun Q, Zhang K, Liu H, et al. Potential role of differentially expressed IncRNAs in the pathogenesis of oral squamous cell carcinoma. Arch Oral Biol 2015; 60: 1581-7.

67. Kolenda T, Guglas K, Ryś M, Bogaczyńska M, Teresiak A, Bliźniak R, et al. Biological role of IncRNA in head and neck cancers. Rep Pract Oncol Radiother 2017; 22: 378-388.

68. Sun O, Liu H, Li L, Zhang S, Liu K, Liu Y, Yang C. Long noncoding RNA $\mathrm{LET}$, which is repressed by EZH2, inhibits cell proliferation and induces apoptosis of nasopharyngeal carcinoma cell. Med Oncol 2015; 32: 226.

69. Zhang W, Wang L, Zheng F, et al. Long Noncoding RNA Expression Signatures of Metastatic Nasopharyngeal Carcinoma and Their Prognostic Value. BioMed Res Intl 2015; 2015: 618924

70. Ren S, Li G, Liu C, et al. Next generation deep sequencing identified a novel IncRNA n375709 associated with paclitaxel resistance in nasopharyngeal carcinoma. Oncol Rep 2016; 36: 1861-7.

71. Chen H, Xin Y, Zhou L, Huang JM, Tao L, Cheng L, Tian J. Cisplatin and paclitaxel target significant long noncoding RNAs in laryngeal squamous cell carcinoma. Med Oncol 2014; 31: 246.

72. Li L, Gu M, You B, Shi S, Shan Y, Bao L, You Y. Long non-coding RNA ROR promotes proliferation, migration and chemoresistance of nasopharyngeal carcinoma. Cancer Sci 2016; 107: 1215-22.

73. Li G, Liu Y, Liu C, et al. Genome - wide analyses of long noncoding RNA expression profiles correlated with radioresistance in nasopharyngeal carcinoma via nest - generation deep sequencing. BMC Cancer 2016; 16: 719 .

74. Zhou J, Li M, Yu W, et al. AB209630, a long non-coding RNA decreased expression in hypopharyngeal squamous cell carcinoma, influences proliferation, invasion, metastasis and survival. Oncotarget 2016; 7 (12): 14628-38.

75. Zhang B, Wang D, Wu J, et al. Expression profiling and functional prediction of long noncoding RNAs in nasopharyngeal nonkeratinizing carcinoma. Discov Med 2016; 21: 239-50.
76. Wang P, Wu T, Zhou H, et al. Long noncoding RNA NEAT1 promotes laryngeal squamous cell cancer through regulating miR-107/CDK6 pathway. J Exp Clin Cancer Res 2016; 35: 22

77. Gonzalez-Ramirez I, Soto-Reyes E, Sanchez-Perez Y, Herrera LA, Garcia-Cuellar C. Histones and long non-coding RNAs: The new insight of epigenetic deregulation involved in oral cancer. Oral Oncol 2014; 50: 691-5.

78. Wu Y, Zhang L, Wang Y, et al. Long non-coding RNA HOTAIR promotes tumor cell invasion and metastasis by recruiting EZH2 and repressing E-cadherin in oral squamous cell carcinoma. Int J Oncol 2015; 46: 2586-94

79. Wang J, Zhou Y, Lu J, Sun Y, Xiao H, Liu M, Tian L Combined detection of serum exosomal miR-21 and HOTAIR as diagnostic and prognostic biomarkers for laryngeal squamous cell carcinoma. Med Oncol 2014; 31: 148

80. Nie Y, Liu X, Qu S, Song E, Zou H, Gong C. Long non-coding RNA HOTAIR is an independent prognostic marker for nasopharyngeal carcinoma progression and survival. Cancer Sci 2013; 104: 458-64.

81. Fu WM, Lu YF, Hu BG, et al. Long noncoding RNA Hot air mediated angiogenesis in nasopharyngeal carcinoma by direct and indirect signalling pathways. Oncotarget 2016; 7: 4712-23.

82. Fang Z, Wu L, Wang L, Yang Y, Meng Y, Yang H. Increased expression of the long non-coding RNA UCA1 in tongue squamous cell carcinomas: a possible correlation with cancer metastasis. Oral Surg Oral Med Oral Pathol Oral Radiol 2014; 117: 89-95.

83. Shen Z, Li O, Deng H, Lu D, Song H, Guo J. Long non-coding rna profiling in laryngeal squamous cell carcinoma and its clinical significance: potential biomarkers for LSCC. PLoS One 2014; 9: e108237.

84. Song P, Ye LF, Zhang C, Peng T, Zhou XH. Long non-coding RNA XIST exerts oncogenic functions in human nasopharyngeal carcinoma by targeting miR-34a-5p. Gene 2016; 592: 8-14.

85. Jia LF, Wei SB, Gan YH, Gou YK, Gong K, Mitchelson K, Cheng J, Yu GY. Expression, regulation and roles of miR-26a and MEG3 in tongue squamous cell carcinoma. Int J Cancer 2014; 135: 2282-93.

86. Liang J, Liang L, Ouyang K, Li Z, Yi X. MALAT1 induces tongue cancer cells' EMT and inhibits apoptosis through Wnt/ $\beta$-catenin signaling pathway. J Oral Pathol Med 2016; 46: 98-105.

87. Wu T, Qu L, He G, et al. Regulation of laryngeal squamous cell cancer progression by the IncRNA H19/miR-148a-3p/DNMT1 axis. Oncotarget 2016; 7: 11553-66.

88. Huang W, Cui X, Chen J, Feng Y, Song E, Li J, Liu Y. Long non-coding RNA NKILA inhibits migration and invasion of tongue squamous cell carcinoma cells via suppressing epithelial - mesenchymal transition. Oncotarget 2016; 7: 62520-32.

\section{Address for correspondence}

\section{Tomasz Kolenda}

Genetic Laboratory

Greater Poland Cancer Centre

Garbary 15

61-866 Poznan, Poland

e-mail: kolenda.tomek@gmail.com

Submitted: 19.10.2017

Accepted: $\quad 27.10 .2017$ 